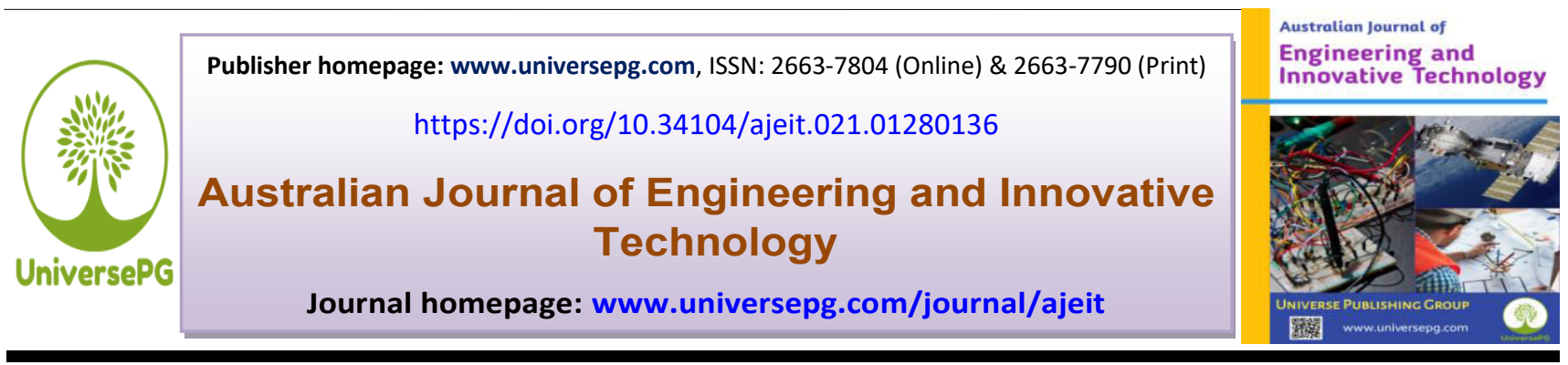

\title{
A Study on the Carbonation Rate of Concrete Exposed in Different Climatic Conditions
}

\author{
Inamullah Inam $^{1}$, Mohammad Khalid Nasiry ${ }^{1}$, Mirwais Sediqmal ${ }^{1}$, Mohammad Nasir Wahdat ${ }^{1}$, Ibadurrahman \\ Momand $^{2}$ \\ ${ }^{1}$ Dept. of Civil Engineering, Laghman University, Mehtarlam, Laghman, Afghanistan; ${ }^{2}$ Dept. of Civil Engineering, \\ Nangarhar University, Jalalabad, Nangarhar, Afghanistan.
}

*Correspondence: inam.azizi@gmail.com (Inamullah Inam, Assistant Professor, Dept. of Civil Engineering, Laghman University, Mehtarlam, Laghman, Afghanistan).

\begin{abstract}
Recently, the degradation of concrete has become a serious problem worldwide and one of the principle factors of degradation is the carbonation process. It is well established that environmental conditions affect the carbonation progress of concrete among the most important factors that can greatly affect the carbonation resistance of concrete are relative humidity $(\mathrm{RH})$ and temperature. Carbonation has become a threat to concrete structures especially in urban and industrial areas. Thus, it is necessary to have a proper design to maintain the structure's stability against degradation caused by carbonation. Therefore, this study was conducted to evaluate the effects of different environmental and climatic conditions on the carbonation rate of concrete. The specimens were prepared using OPC and fly ash (FA). After 28 days of air curing, specimens were exposed in different climate conditions under sheltered and un-sheltered conditions. The carbonation tests were conducted at the ages of 6 and 12 months. It was found that the carbonation rates were significantly influenced by the climate and environmental conditions; the specimens exposed to a relatively dry environment and low annual precipitations have shown higher carbonation during one-year exposure. Moreover, in unsheltered conditions the annual precipitation significantly affects the carbonation rate of concrete. Furthermore, it was observed that a $20 \%$ replacement of FA does not enhance the carbonation resistance of concrete.
\end{abstract}

Keywords: Carbonation rate, Relative humidity, Annual precipitation, Temperature, and Exposure condition.

\section{INTRODUCTION:}

Recently the concrete deterioration has become a serious issue around the world and one of the main factors of deterioration is carbonation. Thus, proper design should be done to avoid concrete deterioration due to carbonation.

When water is added to the mixture of concrete, the hydration process starts and concrete contains cement hydrates and hence is strongly alkaline $(\mathrm{pH}$ : 12-13). Steel bars are protected in a high alkaline environment due to the formation of a passivity film on the surface of the reinforcing bars embed- ded in concrete. However, cement hydrates react with carbon dioxide or other gases present in the air and undergo carbonation, which causes a gradual loss of the alkalinity of concrete (Koichi et al., 2010). In urban and industrial areas due to the high concentration of $\mathrm{CO}_{2}$, carbonation can create more profound carbonated layers in concrete structures. Carbonation of concrete is a physical and chemical process with the passage of time, which is affected by both internal and external factors. The external factors are such as relative humidity (Chen and Ho, 2013; Turcry et al., 2014; Leemann and Moro, 2017), sheltering condition, 
precipitation, $\mathrm{CO}_{2}$ concentration (Lagerblad, 2005; Leemann and Moro, 2017), and temperature from the surrounding environment (Jae-Dong, Hirai \& Mihashi, 1990). Relative humidity plays crucial part in the carbonation resistance of concrete structures. If the concrete specimen is saturated or very dried, the carbonation is effectively stopped (Han et al., 2013; Li et al., 2018).

In saturated conditions, the carbonation progress is stopped and only a proceeds when concrete is enough dried to allow the diffusion of $\mathrm{CO}_{2}$. Moisture in concrete is essential for the chemical reactions of carbonation. The carbonation front reaches the maximum at a relative humidity between 50 and 70\% (Wierig, 1984; Parrott, 1986). At higher relative humidity values above $70 \%$, the carbonation hinders down due to the slower rate of diffusion of $\mathrm{CO}_{2}$ through water-filled pores. At relative humidity values below $50 \%$ there is insufficient moisture to allow carbonation reactions to take place (Ghaforzai, 2021).

In addition to high $\mathrm{CO}_{2}$ concentration, atmospheric temperature can also affect the carbonation of concrete because the rate of the oxidation reaction and $\mathrm{CO}_{2}$ concentration is affected by the amount of heat energy available to drive the reaction. Besides carbonation resistance, the resistance of concrete against chloride penetration is also reduced at elevated temperatures, as ions become more mobile and salts become soluble. This situation can be possibly destructive, and it endangers the resistance of concrete against chloride diffusion because it leads to more portable chloride ions movement. Moreover, Relative humidity influences the permeation properties of concrete (Oberholster, 1986; Parrott, 1994 \& 2006; Basheer, Kropp \& Cleland, 2001). Nagataki et al. have stated in research that air permeability is related to water evaporated from the concrete (Nagataki, Ujike and Konishi, 1986). While internal relative humidity significantly influences the air permeability. It has been observed that increase in $\mathrm{RH}$ reduces the air penetration of the concrete (Parrott, 1991; Saju et al., 2020).

\section{Experimental Program Materials}

In this study, two types of binders namely ordinary Portland cement (OPC), and fly ash are used. Table 1 includes the physical properties of materials. Fly ash is used as a replacement for cement. Crushed stone with a maximum size of $20 \mathrm{~mm}$ was used as a coarse aggregate with density (SSD) of $2.88 \mathrm{~g} / \mathrm{cm}^{3}$, fine modulus (FM) of 6.68 , and water absorption of $0.71 \%$. Washed sea sand was chosen as fine aggregates with density (SSD) of $2.53 \mathrm{~g} / \mathrm{cm}^{3}$, fine modulus (FM) of 2.69, and water absorption: $1.61 \%$. Moreover, tap water was mixed as mixing water for concrete.

\section{Mixture}

Two types of concrete mixtures (OPC and FA) were prepared with $60 \% \mathrm{~W} / \mathrm{B}$. FA content was maintained at $20 \%$ of cement mass. The mix proportion and fresh properties of concrete are shown in Table 2. In order to maintain appropriate fresh properties, both airentraining admixture; and air-entraining and waterreducing admixture were used based on the cement mass.

\section{Specimen Design}

Concrete prism specimens of $75 \times 75 \times 250 \mathrm{~mm}$ and cylindrical specimens with $100 \mathrm{~mm}$ diameters were demolded at 24 hours after casting. Then, the specimens were moved to the temperature and humidity-controlled room. Concrete prisms and cylindrical specimens were stored in an air curing room for 28 days at a constant room temperature of $20^{\circ} \mathrm{C}$ and a relative humidity of $60 \%$. After 28 days curing, 4 sides of the concrete prisms were coated by epoxy while two opposite sides were exposed to $\mathrm{CO}_{2}$ diffusion and after 48 hours waiting for the specimens. The concrete prisms were exposed to $\mathrm{CO}_{2}$ diffusion in accelerated carbonation chamber and natural exposure sites. For natural exposure, four distinct areas were selected; namely Japan, Afghanistan, Indonesia, and Malaysia. Furthermore, the specimens in the natural environment were exposed in sheltered and unsheltered conditions, while the specimens in the accelerated carbonation chamber were kept under constant temperature of $20 \pm 2^{\circ} \mathrm{C}, 60 \%$ relative humidity, and $\mathrm{CO}_{2}$ concentration of $(5 \pm 0.5 \%)$. Moreover, for decreasing the transportation cost the concrete prisms were divided into small cubic $75 \mathrm{~mm}$ along each side.

\section{Testing Method}

Compressive strength test was carried out according to JIS A 1152 at the ages of 28 and 91 days. In addition, the specimens were cured in controlled room air at a constant temperature of $20 \pm 2^{\circ} \mathrm{C}, 60 \% \mathrm{RH}$ until the end of the test age. Accelerated carbonation depth was measured according to JIS A 1153:2003 at certain ages of $1,4,8,13$, and 26 weeks. While for natural exposure specimens, the carbonation test was per- 
formed at the age of 6 and 12 months. At the time of measurement, carbonation depths were measured in the laboratory, the concrete prisms were split, cleaned and $1 \%$ of phenolphthalein in the solution of $90 \%$ ethyl alcohol solution was sprayed on the fresh-cut surface. When the solution is sprayed on a broken concrete surface, the carbonated portion remains colorless (concrete color) and the noncarbonated portion turns to dark purple. Average carbonation depth was measured at 10 points from each side and taken the average carbonation depth at a specific age.

\section{RESULTS AND DISCUSSION:}

\section{Compressive strength}

Fig 1 shows the concrete strength development over a period of 28 and 91 days. The OPC and FA concrete specimens cured in air were tested. The FA was invoked as cement replacement in concrete and FA content was maintained $20 \%$ of cement mass in concrete. It was noticed that the strength increased up to 91 days for both normal OPC concrete and fly ash concrete, while for FA60 specimens the increment was not so significant. N60 (OPC) specimen has shown 17\% development in strength from 28 days to 91 days.

Table 1: Physical properties of materials.

\begin{tabular}{|c|c|}
\hline Material & Description \\
\hline Cement & $\begin{array}{c}\text { OPC } \\
\text { Density }=3.16 \mathrm{~g} / \mathrm{cm}^{3}, \mathrm{SSA}=3330 \mathrm{~cm}^{2} / \mathrm{g}\end{array}$ \\
\hline Flyash & $\begin{array}{c}\text { Fly Ash } \\
\text { Density }=2.26 \mathrm{~g} / \mathrm{cm}^{3}, \mathrm{SSA}=3970 \mathrm{~cm}^{2} / \mathrm{g}\end{array}$ \\
\hline Gravel & $\begin{array}{c}\text { Crushed stone } \\
\text { Density }=2.88 \mathrm{~g} / \mathrm{cm}^{3}, \mathrm{MSA}=20 \mathrm{~mm}\end{array}$ \\
\hline Sand & $\begin{array}{c}\text { Washed Sea sand } \\
\text { Density }=2.53 \mathrm{~g} / \mathrm{cm}^{3}, \mathrm{FM}=2.69\end{array}$ \\
\hline
\end{tabular}

Table 2: Mix proportion and fresh properties of concrete

\begin{tabular}{|c|c|c|}
\hline \multirow{2}{*}{ Materials } & \multicolumn{2}{|c|}{ Mixtures } \\
\cline { 2 - 3 } & $\mathbf{N}-60$ & FA-60 \\
\hline $\mathrm{W} / \mathrm{C}$ & 60 & 60 \\
\hline Water $\left(\mathrm{Kg} / \mathrm{m}^{3}\right)$ & 165 & 165 \\
\hline Cement $\left(\mathrm{Kg} / \mathrm{m}^{3}\right)$ & 275 & 220 \\
\hline Fly ash $\left(\mathrm{Kg} / \mathrm{m}^{3}\right)$ & 0 & 55 \\
\hline Sand $\left(\mathrm{Kg} / \mathrm{m}^{3}\right)$ & 800 & 792.5 \\
\hline Gravel $\left(\mathrm{Kg} / \mathrm{m}^{3}\right)$ & 1114 & 1103 \\
\hline $\mathrm{WR}\left(\mathrm{g} / \mathrm{m}^{3}\right)$ & 1031 & 1031 \\
\hline $\mathrm{AE}\left(\mathrm{mL} / \mathrm{m}^{3}\right)$ & 1586 & 1719 \\
\hline Slump $(\mathrm{mm})$ & 5.5 & 7 \\
\hline Air content $(\%)$ & 4.9 & 3.1 \\
\hline Temperature $\left(\mathrm{C}^{0}\right)$ & 22 & 22 \\
\hline
\end{tabular}

*W: Water, C: Cement, FA: Fly ash as $20 \%$ replace- ment of cement, B: $\mathrm{C}+\mathrm{FA}$

*WR: Water Reducer- $3.0 \mathrm{ml} / 1 \mathrm{~kg}$ of cement

*AE: Air entraining agent- $0.006 \%$ and $0.0065 \%$ of Cement, respectively

*N60: Normal OPC concrete with $60 \%$ W/B

*FA-60: Flyash concrete with $60 \%$ W/B.

*6M: 6 months' exposure and 12M: 12 months of exposure.

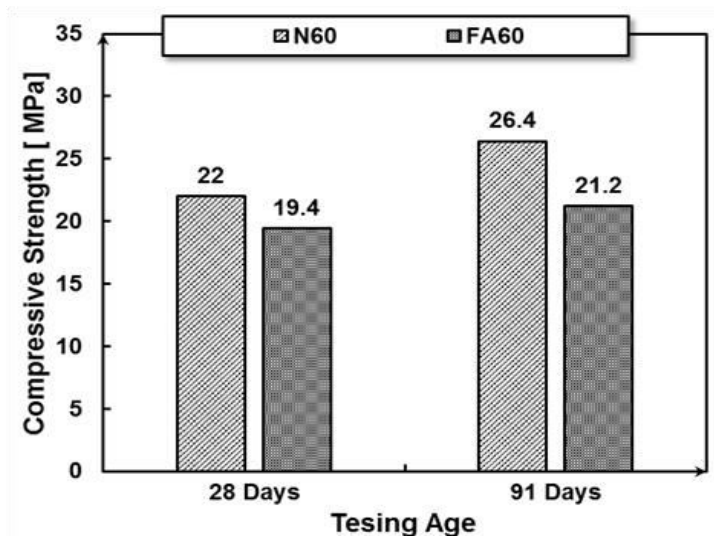

Fig 1: Compressive strength of concrete.

In addition, it was found that by replacing $20 \%$ OPC with fly ash, the strength increased marginally up to 91 days. FA60 specimens only improve $8 \%$, which is negligible compared to normal OPC concrete. Meanwhile, Specimens with $20 \%$ OPC replacement by FA have shown $12 \%$ and $20 \%$ reduction in strength compared with normal OPC at 28 and 91 days, respectively. There could be two reasons for this phenomenon; firstly, this may be due to the effect of the addition of FA addition as a cement replacement, and secondly, the decrease in strength may be the result of slow hydration process, as fly ash are slow-reacting pozzolans (Marthong and Agrawal, 2012; Harison, Srivastava and Herbert, 2014).

\section{Accelerated Carbonation}

Accelerated carbonation depths of concrete with and without FA as partial cement replacement with a W/B ratio of 0.6 at the ages of $1,4,8,13$, and 26 weeks are shown in Fig 2. The carbonation progress was significant for both types of the mixtures due to high W/B ratio and air curing. It can be seen that the carbonation depth increases with the replacement of FA in the concrete compared with those without fly ash which partially replaces the cement. At the end of the testing, fly ash concrete has shown a $16 \%$ increment compared to OPC. From Fig 2, it is clearly seen that OPC incorporation of its own demonstrated less increase in carbonation compared with FA concrete. 


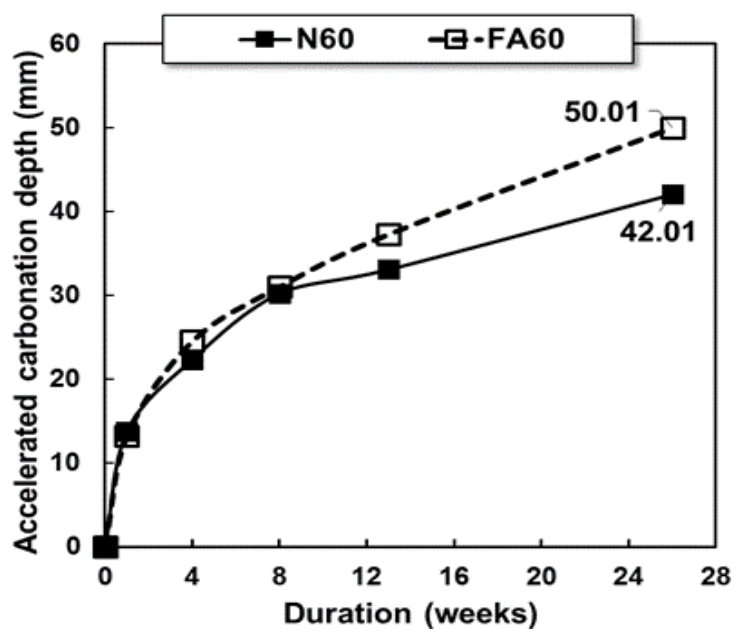

Fig 2: Accelerated carbonation depth.

\section{Natural Exposure}

\section{Exposure climate condition}

Exposure test in the natural environment was conducted in four different regions such as Kabul (Afghanistan), Fukuoka (Japan), Makassar (Indonesia), and BatuPahat (Malaysia). Different regions have different climates and environmental conditions. Every region climate condition has been briefly introduced, and the data has been plotted. The annual average temperature, relative humidity, and rainfall amount for all the exposure sites are briefly described below.

a) Fukuoka is the capital city of Fukuoka prefecture, situated on the northern shore of Kyushu island in Japan. It has a humid subtropical climate with hot humid summers and relatively mild winters. The average annual precipitation is around $1600 \mathrm{~mm}$, while the actual precipitation demonstrated in Fig 3 from Aug 2014 up to Aug 2015 was measured around $2240 \mathrm{~mm}$. The high intensity of rainfall was recorded between the months of June and September, which can be seen in Fig 3. Fukuoka city has a moderate climate with an annual average temperature of $17.3{ }^{\circ} \mathrm{C}$, an average $\mathrm{RH}$ of $70 \%$. The temperature drops to below $0{ }^{\circ} \mathrm{C}$ in the winter season, while the maximum temperature reaches to $37{ }^{\circ} \mathrm{C}$ in the summer season with supper humidity (Climate Data for Fukuoka, 2014).

b) Kabul is the capital of Afghanistan, located in the eastern part of Afghanistan. Kabul has a semiarid climate with cold winters and hot summers. The annual temperature at the exposure area (close to the specimen) was around $16.5^{\circ} \mathrm{C}$ and the average humidity of $45 \%$. It has four seasons the same as Fukuoka city in Japan. In winter, the temperature goes down below $0{ }^{\circ} \mathrm{C}$ and the precipitation is concentrated in January almost exclusively falling as snow, while the summer is hot and dry. The dry season is usually started in June and prolongs up to the end of August. The maximum temperature recorded in July was almost $38{ }^{\circ} \mathrm{C}$. Fig 4 illustrates the climatic data measured by using hydrometer equipment placed near the specimens from 20142015.

c) Makassar is the capital of the Indonesian province of South Sulawesi. Makassar / Ujung Pandang have a tropical monsoon climate characterized by heavy rains, high humidity, high temperatures and mild winds with short dry seasons. Generally, the weather is hot and humid. Indonesia's climate is divided into two seasons: dry and wet. Most of Indonesia has its rainy seasons from October through April. The dry season lasts from April to October, but the dry season lasts from August to October, when the intensity of the dry season is high(Climate - Indonesia - average, annual, temperature, 2014). The dry season does not mean that there are no rains. The annual precipitation is $1800 \mathrm{~mm}$. In Fig 5 the annual average temperature is $28{ }^{\circ} \mathrm{C}$, while the relative humidity rages around $75 \%$ to $85 \%$.

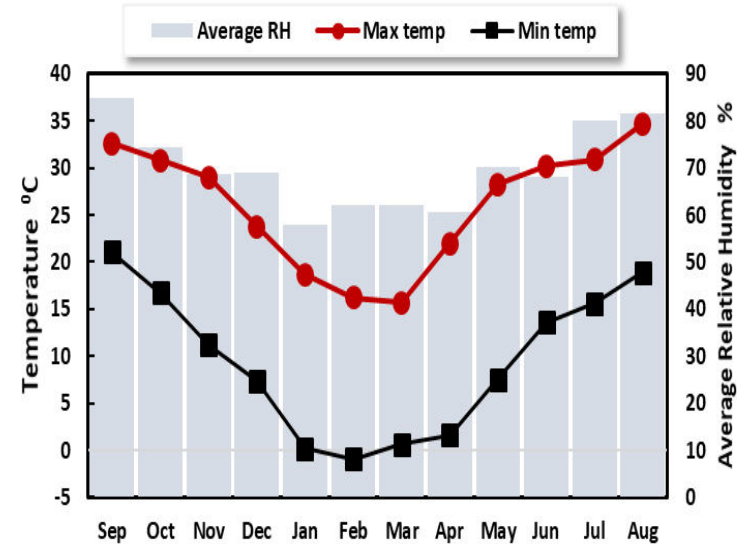

Fig 3: The climate data for Fukuoka (2014-2015).

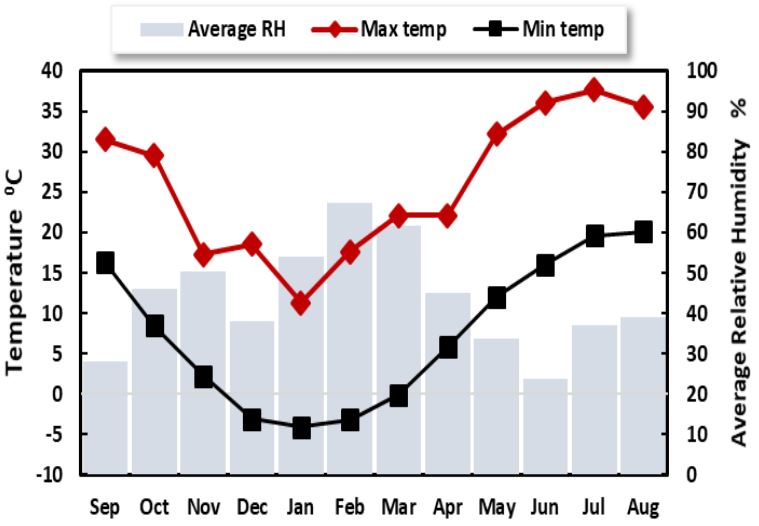

Fig 4: The climate data for Kabul (2014-2015). 
d) BatuPahat: Region of Johor State, Malaysia. The climate of BatuPahat is classified as tropical and is divided into two seasons: dry and wet. The temperature here averages $27.0{ }^{\circ} \mathrm{C}$. Annual precipitation is about $2308 \mathrm{~mm}$, with an average temperature of $27.5{ }^{\circ} \mathrm{C}$. April is the hottest month of the year. The lowest average temperatures in the year occur in January, when it is around $26.9{ }^{\circ} \mathrm{C}$. The relative humidity ranges between $80-90 \%$ (Fig 6).

\section{Carbonation rate in natural exposure}

Carbonation depth was measured at the ages of 6 months and 12 months for all exposure sites. The specimens were kept in the sheltered and unsheltered conditions. The test results for both conditions are illustrated from Fig 7 up to Fig 10. Fig 7 represents the carbonation progress for the specimens exposed in Kabul, Afghanistan. The results are shown for 6 months and 12 months, both N60 and FA60 have shown significant increase in carbonation depth, and the similar trend to the accelerated carbonation depth shown in Fig 2 . Furthermore, a strong relationship between carbonation development and exposure time for all concrete mixture was achieved. From the results, it can be seen that the carbonation depth is low in unsheltered conditions, which is influenced by rainfall and snowfall during the rainy season, but it is not so significant due to less amount of annual rainfall, which is around $316 \mathrm{~mm}$. In the case of FA60 specimen, no significant difference has been seen for 6 months' exposure because the exposure started from Aug 2014, and from Aug- Jan the rainfall is less in amount. Therefore, fly ash concrete did not show the good resistance to $\mathrm{CO}_{2}$ diffusion because fly ash affect sheat of hydration and the strength development becomes slow and resulting low carbonation resistance. In sheltered conditions, N60 and FA60 specimens have shown $40 \%$ and $47 \%$ increment in carbonation depth during 6 months respectively. While in unsheltered conditions, N60 and FA60 showed 46 and 39\% the increment in carbonation depth, respectively.

Carbonation front progress in the Japanese environment is demonstrated in Fig 8, the trend of the carbonation progress under sheltered conditions is roughly the same as measured for the specimens exposed in Kabul. The increment was also same as mentioned above. More or less, for all exposure sites in normal conditions, the carbonation progress had a linear relationship with exposure time and increased with increasing exposure time. Furthermore, the concrete incorporating FA as cement replacement generally showed lower resistance to carbonation in natural exposure compared to OPC concrete, which has also been confirmed by the accelerated carbonation test presented in Fig 2, possibly due to the dominant effect of calcium hydroxide reduction on pore refinement. In addition, fly ash concrete has exhibited the larger carbonation depth under all exposure conditions (Khunthongkeaw, Tangterm-sirikul and Leelawat, 2006).

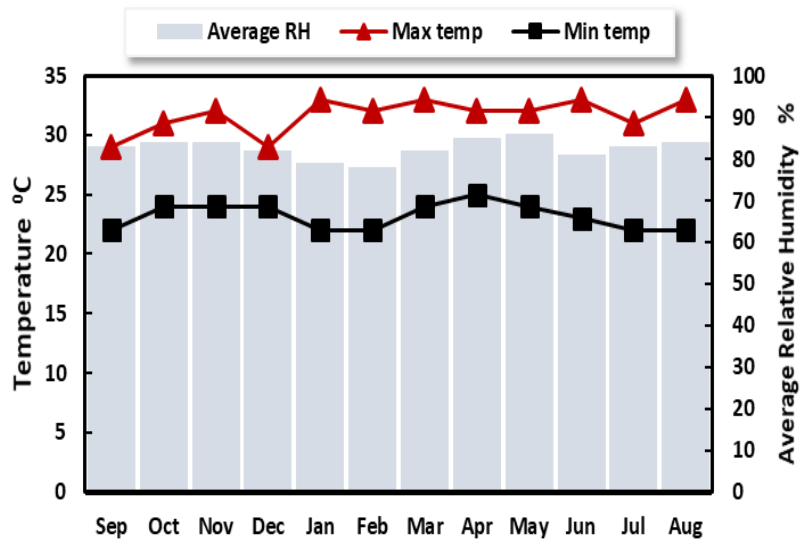

Fig 5: Climate data for Makassar (2014-2015).

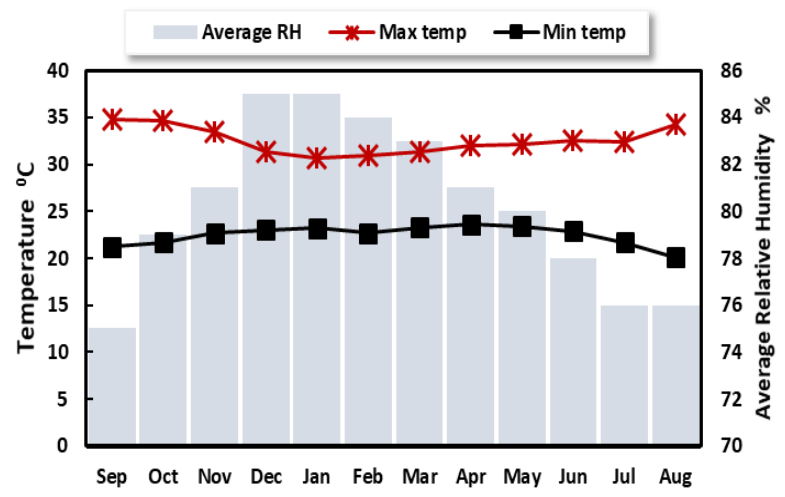

Fig 6: Climate data for BatuPahat (2014-2015).

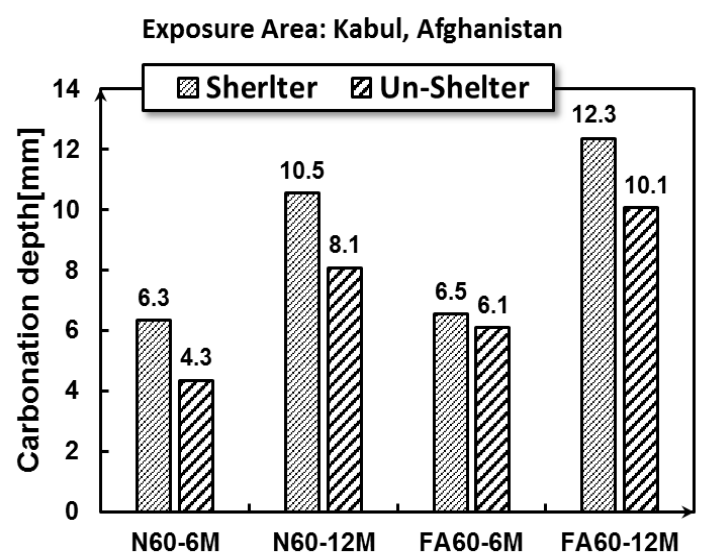

Fig 7: Natural carbonation depth Kabul, Afghanistan. 
Moreover, the results represented in Fig 8 were measured for unsheltered conditions, which were remarkably different from the sheltered condition, the lower carbonation depths were obtained in the high rainfall environment. From Fig 7 and Fig 8, it can be concluded that environmental conditions have a great influence on the carbonation process of concrete. Concrete has a lower carbonation resistance in sheltered condition than unsheltered condition, where the concrete is no longer protected from rain. Fig 9 shows the carbonation front progress through one year in Makassar. The specimens show the same trend as it is illustrated in Fig $\mathbf{7}$ and Fig 8. The climatic conditions of Indonesia are different from Afghanistan and Japan. High annual average temperature and humidity; the researches show, that carbonation occurs faster in warmer regions or sheltered conditions. Somewhat this statement is true for all exposure conditions at sheltered exposure sites, whereas it can be observed that despite the fact that Indonesia's annual temperature is higher than that of Afghanistan and Japan, but the carbonation depth is still lower than the other two regions, possibly due to the high relative humidity in Indonesia. Concrete face higher carbonation in high temperature unless the relative humidity is lower (Koichi et al., 2010). Fig 10 represents the carbonation progress of specimens exposed in the Malaysian environment. It is demonstrated that carbonation rates for the first six months of the exposure was significant, while the increment for all types of the mixture was negligible until 1 year. The increment in the first six months can be attributed to the dry weather conditions from January to March, and from March to February is usually the rainy season in Malaysia, which causes less increment in carbonation from six months.

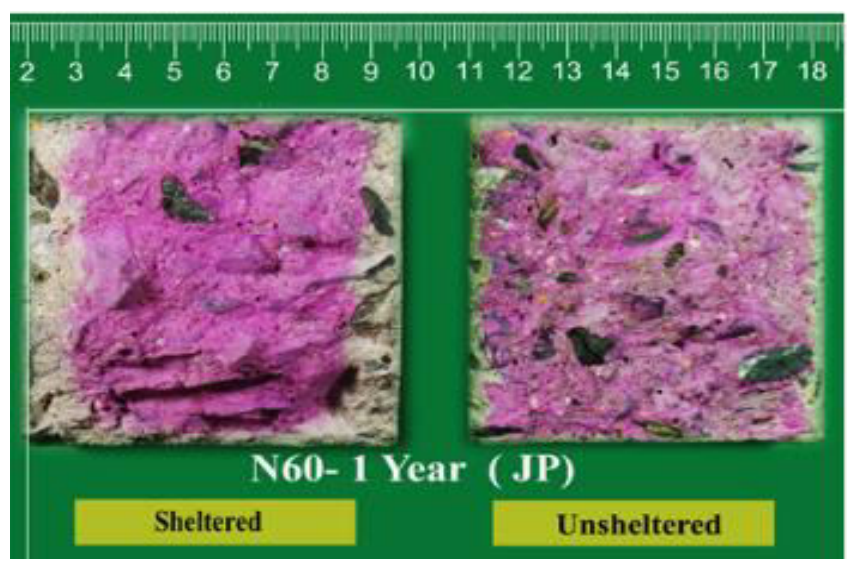

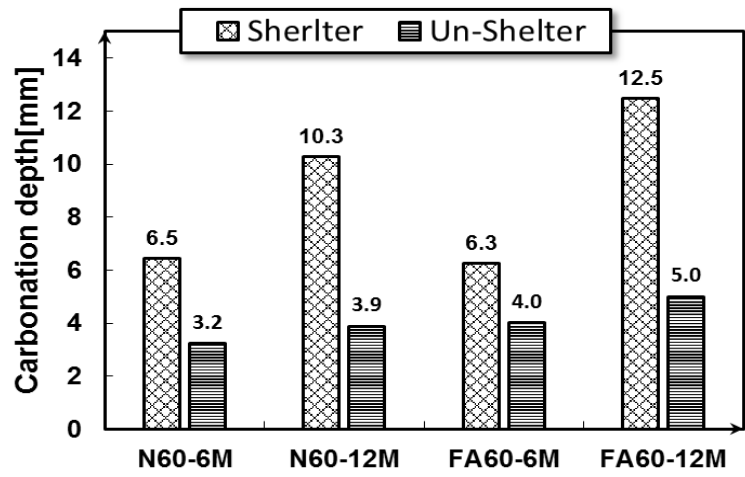

Fig 8: Natural carbonation depth in Fukuoka.

Exposure Area: Makassar, Indonesia

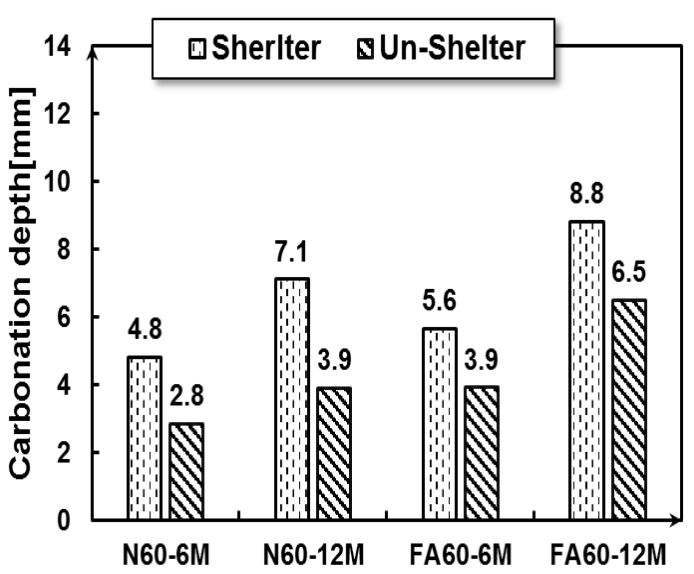

Fig 9: Natural carbonation depth in Makassar.

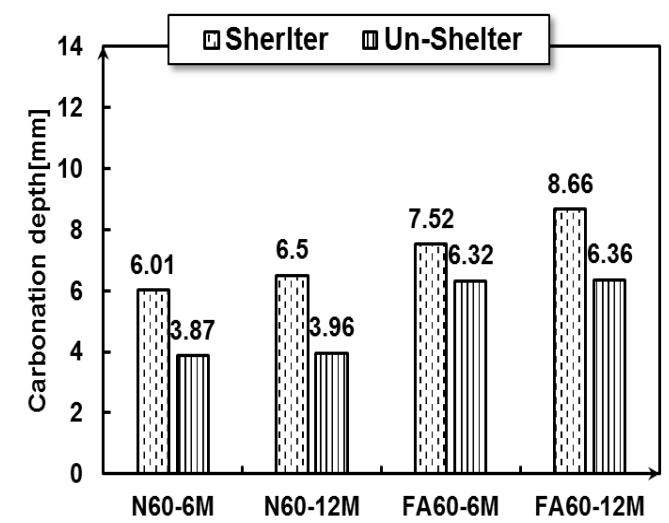

Fig 10: natural carbonation depth in BatuPahat.

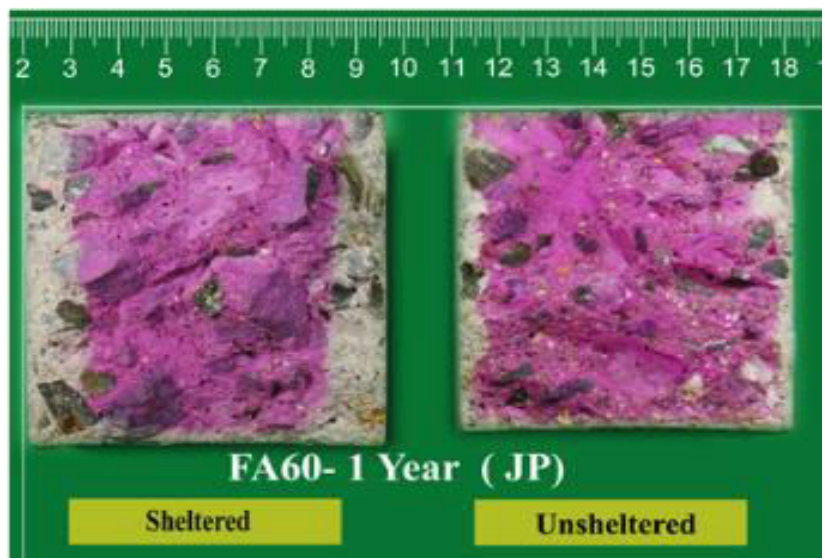

Photo 1: Graphical representation of carbonation for Fukuoka, Japan exposure site. 

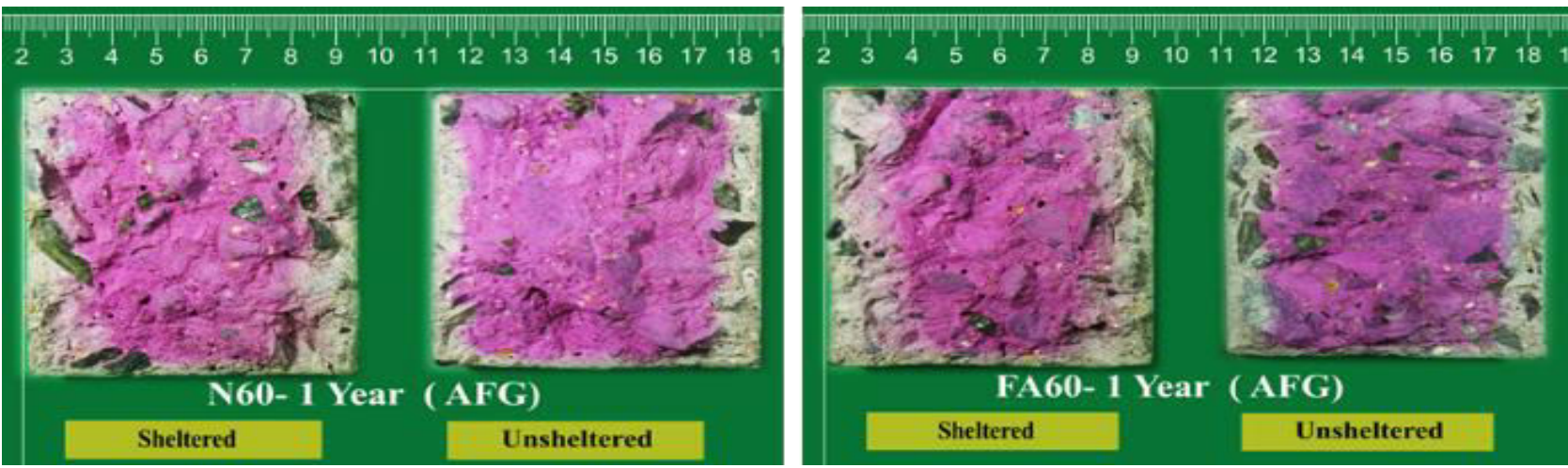

Photo 2: Graphical representation of carbonation for Kabul, Afghanistan exposure site.
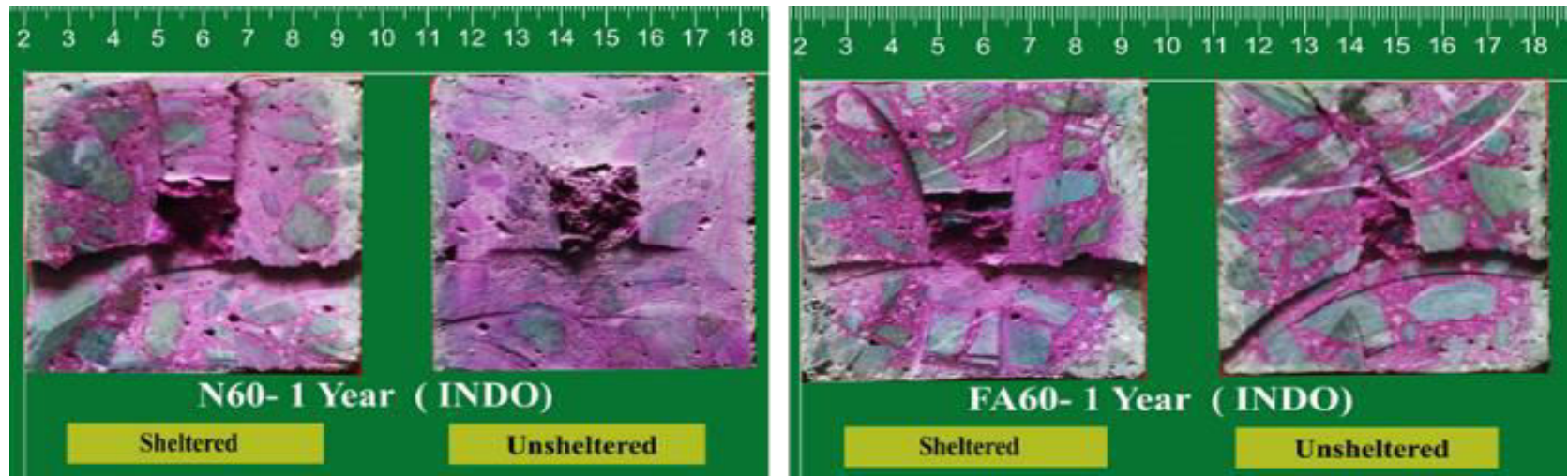

Photo 3: Graphical representation of carbonation for Makassar, Indonesia exposure site.
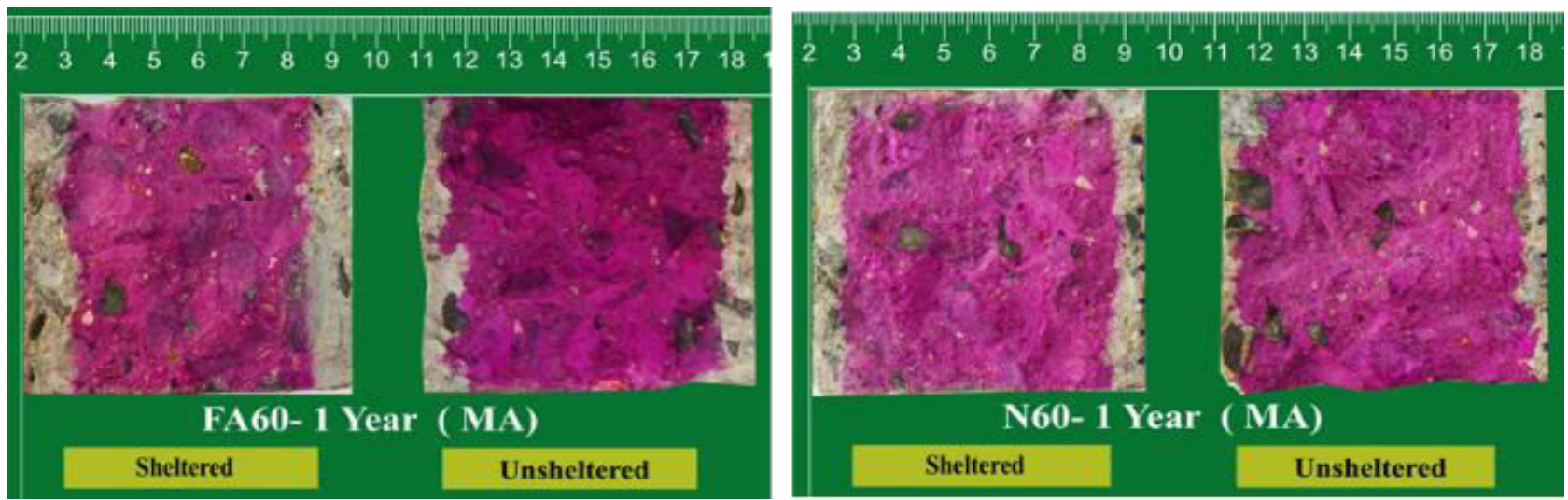

Photo 4: Graphical representation of carbonation for Japan exposure site.

This means that the drying and wetting processes have a great effect on the carbonation progress. The carbonation front after 1 year is also presented in the photo (1-4).

\section{CONCLUSION:}

The carbonation rate of all concrete mixtures apparent to natural exposure is significantly affected by the climatic conditions; Concrete exposed to a relatively dry environment has shown a higher rate of carbonation during the exposure time. It can be seen that the carbonation rate is higher when the $\mathrm{RH}$ is in the range of $45-70 \%$. In addition, the carbonation rate is affected by the rainfall amount; the lower the rainfall the lower the carbonation rate. In Afghanistan, due to low annual rainfall and relative dry season, higher carbonation is observed.

\section{ACKNOWLEDGEMENT:}

The authors would like to thank Kyushu university concrete engineering Laboratory for providing research facilities and as well the Hasanuddin University, Indonesia and University Tun Hussein Onn Malaysia (UTHM) for assistance in conducting exposure test.

\section{CONFLICTS OF INTEREST:}

All authors declare that they have no conflicts of interest to disclose. 


\section{REFERENCES:}

1) Basheer, L., Kropp, J. and Cleland, D. J. (2001) 'Assessment of the durability of concrete from its permeation properties: A review', Construction and Building Materials, 15(2-3), pp. 93-103.

\section{https://doi.org/doi:10.1016/S0950-0618(00)000}

58-1

2) Chen, C. T. and Ho, C. W. (2013) 'Influence of cyclic humidity on carbonation of concrete', Journal of Materials in Civil Engineering, 25 (12), pp. 1929-1935.

https://doi.org/10.1061/(ASCE)MT.1943-5533.0 $\underline{000750}$

3) Climate - Indonesia - average, annual, temperature (no date). Available at:

http://www.nationsencyclopedia.com/Asia-andOceania/Indonesia-CLIMATE

4) Climate Data for Fukuoka (no date). Available at: http://www.data.jma.go.jp/gmd/risk/obsdl/ind ex.php\#

5) Ghaforzai A, Ullah S, and Asir M. (2021). Household waste management in formal housing developments in Afghanistan: a case study of Kabul city. Aust. J. Eng. Innov. Technol., 3(4), 64-72.

https://doi.org/10.34104/ajeit.021.064072

6) Han, S. H., Park, W. S. and Yang, E. I. (2013) 'Evaluation of concrete durability due to carbonation in harbor concrete structures', Construction and Building Materials. Elsevier Ltd, 48, pp. 1045-1049.

https://doi.org/10.1016/j.conbuildmat.2013.07.057

7) Harison, A., Srivastava, V. and Herbert, A. (2014) 'Effect of Fly Ash on Compressive Strength of Portland Pozzolona Cement Concrete', Journal of Academia and Industrial, 2(8), pp. 476-479.

https://doi.org/10.4028/www.scientific.net/AMM. 754-755.447

8) Jae-Dong, J., Hirai, K. and Mihashi, H. (1990) 'Influence of Environmental Moisture and Temperature on Carbonation of Mortar', Concrete Research and Technology, pp. 85-94. https://doi.org/10.3151/crt1990.1.1_85

9) Khunthongkeaw, J., Tangtermsirikul, S. and Leelawat, T. (2006) 'A study on carbonation depth prediction for fly ash concrete', Construction \& Building Materials, 20(9), 744-753. https://doi.org/10.1016/j.conbuildmat.2005.01.052

UniversePG I www.universepg.com
10) Koichi, M. et al. (2010) 'Effect of Humidity on Rate of Carbonation of Concrete Exposed to High-Temperature Environment', International Symposium on the Ageing Management \& Maintenance of Nuclear Power Plants, 109-114. http://nisaplm.jp/html/img/04_reseach/PDF/Concr ete Durability-2.pdf

11) Lagerblad, B. (2005) Carbon dioxide uptake during concrete life cycle - State of the art. Swedish Cement and Concrete Research Institute.

12) Leemann, A. and Moro, F. (2017) 'Carbonation of concrete: the role of $\mathrm{CO} 2$ concentration, relative humidity and $\mathrm{CO} 2$ buffer capacity', Materials and Structures/Materiaux et Constructions. Springer Netherlands, 50(1), pp. 30. https://doi.org/10.1617/s11527-016-0917-2

13) Li, D. et al. (2018) 'Evaluating the effect of external and internal factors on carbonation of existing concrete building structures', Construction and Building Materials. Elsevier Ltd, 167, pp. 73-81.

https://doi.org/10.1016/j.conbuildmat.2018.01.127

14) Marthong, C. and Agrawal, T. P. (2012). 'Effect of Fly Ash Additive on Concrete Properties', 2(August), pp. 1986-1991.

15) Nagataki, S., Ujike, I. and Konishi, N. (1986) 'Influence of moisture content on air permeability of concrete', in Review of 40th Meeting of Cement Association of Japan, Tokyo, pp. 158-161.

16) Oberholster, R. E. (1986). 'Pore structure, permeability and diffusivity of hardened cement paste and concrete in relation to durability: status and prospects', in $8^{\text {th }}$ International congress on chemistry of cement, pp. 324-335.

17) Parrott, L. (1986) 'Measurement and modeling of porosity in drying cement paste', MRS Online Proceedings Library (OPL). Cambridge University Press, 85.

https://doi.org/10.1557/PROC-85-91

18) Parrott, L. J. (1987) 'Measurement and modeling of moisture, microstructure and properties in drying concrete', in 1st International RILEM Congress, Versailles, France, pp. 135-142.

19) Parrott, L. J. (1991) 'Factors influencing relative humidity in concrete', Magazin of Concrete Research, 43(154), pp. 45-52. https://doi.org/10.1680/macr.1991.43.154.45

20) Parrott, L. J. (1994). 'Moisture conditioning and transport properties of concrete test specimens', 
Materials and structures. Springer, 27(8), p. 460.

21) Parrott, L. J. (2006). 'Assessing carbonation in concrete structures', in Durability of building materials and components. Spon Press, pp. 622-633.

22) Saju JA, Rubel SNR, Rahman MM, Nayan SB, and Bagchi R. (2020). Effectiveness of manual bar screen in separating solid waste from municipal sewers of Khulna city, Aust. J. Eng. Innov. Technol., 2(3), 31-41. https://doi.org/10.34104/ajeit.020.031041
23) Turcry, P. et al. (2014). 'Analysis of an accelerated carbonation test with severe preconditioning', Cement and Concrete Research, 57, pp. 70-78.

https://doi.org/10.1016/j.cemconres.2014.01.003

24) Wierig, H. J. (1984) 'Longtime studies on the carbonation on concrete under normal outdoor exposure', in Rilem Seminar Durability of Concrete Structures Under Normal Outdoor Expouser, pp. 239-249.

Citation: Inam I, Nasiry MK, Sediqmal M, Wahdat MN, and Momand I. (2021). A study on the carbonation rate of concrete exposed in different climatic conditions. Aust. J. Eng. Innov. Technol., 3(6), 128-136. https://doi.org/10.34104/ajeit.021.01280136 @ @ 